\title{
Kina er kommet på niveau med USA
}

\section{Hugo Gården}

Deng Xiaoping pålagde samtidens kinesiske ledere, at de skulle vælge deres kampe med omhu. Kina skal "gemme sin styrke og vente på, at tiden er inde.” Det er den øjensynlig nu, men indenrigspolitiske problemer hober sig op, og Nordkorea kan blive prøven på Kinas udenrigspolitiske styrke

Det er lidt af en skæbnens ironi, at Kina formåede at vriste det globale eneherredømme fra USA, netop mens der herskede usikkerhed om den kommende kinesiske leder, $\mathrm{Xi}$ Jinping. I den første uge af september sidste år forsvandt vicepræsident $\mathrm{Xi}$ Jinping fra den vestlige medieverdens radarskærme, og det gav anledning til spekulationer om sygdom og magtkamp. Han aflyste et par møder med udenlandske ledere, $\mathrm{fx}$ USA's daværende udenrigsminister Hillary Clinton.

Men da han dukkede op igen, var det med mere hårdtslående budskaber end tidligere om det mest betændte, aktuelle emne i regionen, nemlig om Senkaku/Diaoyu-øerne. Han kaldte den japanske regerings $k ø b$ af øerne for en farce, og han advarede Japan mod at forsøge at underminere Kinas territorium og integritet.

Det mest afgørende var dog hans møde med den besøgende daværende amerikanske forsvarsminister, Leon Panetta. Ifølge nogle kilder fik Panetta en 'lussing', fordi Xi eftertrykkeligt bad USA om at holde fingrene fra den kinesisk-japanske strid om øerne, som Japan annekterede i 1895, men som Kina hævder hører til Kina.

Panetta udtrykte efter mødet en neutral amerikansk linje. Han understregede, at USA ikke har indtaget en holdning til det, han kaldte striden om territorier mellem de to lande. Dernæst sagde han, at den 
sikkerhedspolitiske amerikanske kursdrejning (dét amerikanerne kalder 'pivot') mod Asien ikke skal opfattes som et forsøg på at indhegne (hedging) eller begrænse Kina (containment), men tværtimod som "et forsøg på at engagere Kina og ekspandere landets rolle i Stillehavsregionen."

Den sidste bemærkning virker letkøbt, eftersom kursdrejningen fra efteråret 2011 ikke blev begrundet i et forsøg på at engagere Kina kraftigere, og eftersom USA forsøger at opbygge et Stillehavs-EU bevidst uden kinesisk deltagelse. Tidligere udenrigsminister Hillary Clinton har været den mest kritiske af de amerikanske ministre over for Kina og har talt varmt om at støtte Kinas nabolande i striden om Det Sydkinesiske Hav, som hun har kaldt for Det Vestfilippinske Hav, ligesom hun har sagt, at fri skibspassage i verdens mest befærdede farvand hører til USA's interessefelt. Det er indlysende, at den slags udtalelser betragtes som provokerende i Beijing.

\section{Da billedet vendte}

Billedet vendte abrupt i september, netop mens Kina stod over for sit lederskifte i kommunistpartiet og siden hen - i marts i år - i regeringen. Der var ikke en synlig militær eller økonomisk konfrontation, men begivenhederne viste, at Kina var kommet på niveau med USA, og at USA ikke længere kan sætte dagsor- denen over for Kina, når Kinas vitale interesser er på spil - heller ikke sikkerhedspolitisk.

Udfaldet af den politiske styrkeprøve minder om den kinesiske krigsteoretiker Sun Tzus filosofi: at den bedste sejr er den, der bliver afgjort inden et militært slag.

Det skal tilføjes, at denne vurdering af begivenhederne kun er en fortolkning. Kina-iagttagere er ikke blevet meget bedre end fortidens kremlologer eller Mao-iagttagere var til at forudsige, hvad der sker bag de lukkede mure i autoritære samfund. Det skyldes i høj grad, at mange har svært ved at se, at Kina er en verden for sig selv, som den tidligere amerikanske udenrigsminister Henry Kissinger har beskrevet indgående i sin bog On China.

Han falder ikke just på halen over Obama-regeringens Kina-politik, og det samme gælder hans senere sikkerhedspolitiske kollega, Zbigniew Brzezinski, der advarer USA mod at gøre Kina til den store skurk, og som mener, at etableringen af en amerikansk militærbase i Australien kun skaber modvilje i Kina uden at styrke USA på nogen måde.

De to er et par kølige realpolitiske tænkere med sans for historien, og hverken realpolitik eller historie belaster alle vestlige politikeres og iagttageres vurdering af Kina. Obama udtrykker den generelle vestlige opfattelse, at Vesten gerne ser et stærkt samarbejde med Kina, så længe Kina bevæger sig henimod den vest- 
lige samfundsform, dvs. mod demokrati og i respekt for den kendte verdensorden.

Præsident Barack Obama har udtrykt det ved at sige, at Kina "skal følge spillereglerne.” Men hvilke spilleregler? Dem, der er fastsat af Vesten, er ikke nødvendigvis dem, som Kina betragter som spillereglerne, og da den økonomiske fremtid hører Kina og vækstlandene til, vil vi uvægerligt se diskusioner og formentlig konflikter om spillereglerne.

\section{Kinas nye handlekraft}

Under et besøg i Canberra sidste år sagde Barack Obama, at fascismens og kommunismens modeller fejlede, fordi de ignorerer folkets vilje. Han kommenterede Kinas enorme $\varnothing$ konomiske fremskridt ved at sige, at "fremskridt uden frihed blot er en anden form for fattigdom." Disse bemærkninger vakte fortørnelse i Beijing, fordi Obama ignorerede fremskridtene for den kinesiske befolkning, og fordi han ikke viste forståelse for den kinesiske model med statslig topstyring og en buldrende kapitalisme. Men kineserne ryster også på hovedet over den selvskabte amerikanske finanskrise og politikernes vanskeligheder ved at løse fundamentale økonomiske problemer.

Kinesernes fremskridt og Vestens stagnation har skabt en betydelig selvtillid i Kina, og ikke bare i topledelsen.
Kina har fået en handlekraft, som USA og fx Japan ikke længere har. Kina har formået at fordoble sin økonomi fra 2000 til 2010, og en ny fordobling ventes til 2020. Det får kineserne til at erkende, at deres skæbne ikke længere afhænger af Vesten.

Selvsikkerheden blev udtrykt i ét ord, da Xi Jinping besøgte Obama i Det Hvide Hus i februar sidste år. Obama spurgte, om de to lande ikke skulle etablere en 'rød telefonlinje' som mellem Washington og Moskva. Xi's svar var: 'Nej.'

Den selvsikkerhed blev glemt af mange vestlige journalister og eksperter under affæren om Bo Xilai. Affæren blev vurderet som udtryk for dybe problemer i det kinesiske samfund og i magtstrukturen. Der er ingen tvivl om, at magten blev rystet, først og fremmest fordi en enkeltperson forsøgte at komme til tops via en lokal folkestemning. Men udviklingen har siden hen vist, at partiet har evnet at håndtere affæren særdeles sikkert og måske styrket sin position. Ledelsen har erkendt behovet for politiske reformer og for at rydde op i magtmisbrug og korruption. Samtidig har affæren vist, at topledelsen er parat til at bruge muskler udadtil, og det kommer især til udtryk med Xi Jinpings handlinger.

Der var sidste år spekulationer om, at han ikke ville blive leder af Militærkommissionen før et halvt eller helt år efter magtovertagelsen, 
og at præsident $\mathrm{Hu}$ Jintao ville bevare denne post for at have hånd $\mathrm{i}$ hanke med Xi. Men Hu overlod tøjlerne til Xi i forbindelse med magtskiftet i partiet i efteråret, og Xi har formentlig også styrket sin position derved, at politbureauets stående udvalg - magtens centrum - er blevet reduceret fra ni til syv medlemmer.

\section{Kerneinteresser}

Men det måske mest afgørende var, at $\mathrm{Xi}$, der skønnes at have bedre forbindelse til militæret end $\mathrm{Hu}$, fra sidste sommer ledede et strategi-arbejde om Senkaku/Diaoyu-øerne, og dermed om udviklingen af en strategi for forholdet til Japan, nabolandene og USA. Da strategien blev drøftet og fastlagt, var Xi stadig kun viceformand i Militærkommissionen. Han var klædt på til mødet med $\mathrm{Pa}-$ netta i september.

Da han var blevet valgt som partiformand, gik hans første officielle rejse $i$ Kina til den sydlige del af landet, hvor de økonomiske reformer begyndte under Deng Xiaoping, og hvor hans far, Xi Zhongxun, spillede en afgørende rolle. Faderen var også en af de førende militærchefer under borgerkrigen.

Under besøget i det sydlige Kina sagde Xi til de militære chefer i Guangdong, at hæren skal gøre sig "klar til reelle kamphandlinger." Han bekræftede hærens kerneopgave, nemlig at vinde regionale krige og at kunne håndtere forskelligartede militære operationer. En professor ved marineakademiet, Li Jie, hæftede sig ved, at Xi's udtalelser kom netop, mens spændingerne om ø-gruppen voksede, og han betegnede udtalelsen som en nødvendig udmelding.

Det er langt fra givet, at Xi Jinping dermed lagde op til militære konfrontationer, men man ser en klar linje: Først kom der et politisk opgør med USA, som førte til, at USA indtog en neutral linje mellem Kina og Japan på dette specifikke område, og dernæst udtrykte Xi sig mere selvbevidst end tidligere om forhold, der kan betragtes som vitale.

Den amerikanske regering burde allerede under Xi's USA-besøg have set de nye kinesiske signaler, for $\mathrm{Xi}$ krævede, at USA skal respektere Kina's 'kerne-interesser' som han udtrykte det, og dermed mente han bl.a. Tibet og Taiwan. Han har siden hen brugt udtrykket 'kerne-interesser' flere gange, og det er utvivlsomt udtryk for, at Kina mere end tidligere er parat til at forsvare dem.

Deng Xiaoping appellerede altid til samtidens ledere, at de ikke skulle bruge kræfter på følsomme temaer, hvis det ikke var nødvendigt. Han sagde, at Kina skal "gemme sin styrke og vente på, at tiden er inde." Det er den øjensynlig nu. Derfor kunne Xi under sig besøg i USA sige, at det kinesisk-amerikanske forhold er gnidningsfrit, når begge lan- 
de respekterer hinandens kerne-interesser, men at "der uafladeligt er problemer, når det modsatte sker."

\section{USA bør dele med Kina}

Professor Jin Canrong, Renmin Universitet, sagde i november til New York Times, at Xi udfordrer USA's globale lederskab ved at sige, at USA skal give plads til Kina's voksende magt. "Kina bør være med til at løfte det ansvar, som USA har, og USA bør dele noget af dets magt med Kina. Men eliten i USA bryder sig ikke om det, omend eliten må acceptere det," sagde han.

Under partikongressen i efteråret og siden hen har Xi talt om 'den kinesiske drøm', nemlig om en stor fornyelse eller genskabelse af nationen. Det er et udtryk, der skal få kineserne til at være lige så stolte over deres egen situation, som amerikanerne er over den amerikanske drøm.

Når Xi taler om drømmen, så fremhæver han i samme åndedrag, at Kina vil arbejde positivt for at løse internationale problemer, men at Kina aldrig vil opgive sine kerneinteresser, og at "vi aldrig vil sluge den bitre frugt," som det vil være tilfældet, hvis det svigter sine egne interesser.

Han udtrykker dermed mere klart end tidligere ledere, at Kina har fået styrken til at forsvare sine interesser. Men det er samtidig tydeligt, at begge lande befinder sig i uprøvede far- vande. Hvad vil USA med sin asiatiske drejning, når Kina uventet - set fra amerikansk side - svarer igen? Den amerikanske sikkerhedsrådgiver i den første Obama-periode, Tom Donilon, sagde i november, at Obama i sin anden regeringsperiode vil føre en Kina-politik, der består af en balance mellem samarbejde og konkurrence.

Det er der utvivlsomt større chance for under en udenrigsminister John Kerry end under forgængeren Hillary Clinton. Men hvordan skal det udmøntes, når USA fx vil holde Kina uden for et nyt Stillehavs-fællesskab?

Donilon lagde vægt på multilaterale forhandlinger om eventuelle problemer, men Kina lægger vægt på bilaterale forhandlinger. Hvordan skal det forenes? Og hvad giver de bedste resultater, når erfaringen er, at de mest holdbare resultater generelt kommer i kraft af bilaterale aftaler? Den amerikanske strategi flagrer altså. Den amerikanske 'contain and engage'strategi kan let ende i containment.

Heller ikke den kinesiske strategi er fri for at flagre, men den synes at bygge på et mere solidt grundlag end den amerikanske. Den tager udgangspunkt i egne interesser og ikke i at udbrede eller forsvare nogle principper på globalt plan. Mere end tidligere er Kina ved at bygge fundamentet for en international politik, der tager udgangspunkt i Kinas interesser som økonomisk su- 
permagt, men som også skaber mere klarhed om Kinas position - nemlig ved at sikre Kinas urørlighed i forhold til andre lande og ved at sikre Kinas interesser i sine nærområder. I nær fremtid er det utænkeligt, at Kina vil forsøge at opbygge alliancer og forsvarsaftaler over hele kloden, som USA gør det.

Kina og USA står dermed i fundamentalt forskellige positioner med vidt forskellige strategiske interesser i deres respektive udenrigspolitik, og det minder om magtbalancen mellen Storbritannien og Tyskland inden Den første Verdenskrig: En global kolonimagt contra en relativt afgrænset, men stærkt voksende centraleuropæisk magt. Briterne var bange for, at tyskerne ville stække dem, og det bidrog ifølge Kissinger til Første Verdenskrig. Tilsvarende var tyskerne bange for, at briterne ville hindre tyskerne $i$ at vokse $u d$ af den europæiske ramme. Begge så foran sig en trussel, som måske ikke var der.

Når den kinesiske udenrigspolitik viser en vis uklarhed, så skyldes det også, at det er uvist, om Kina vil finde multilaterale eller bilaterale løsninger på fx konflikterne i det Østog Sydkinesiske Hav. Hidtil har Kina lagt op til bilaterale løsninger og vil i hvert fald ikke have internationale løsninger med amerikansk deltagelse. Men kineserne kunne dog være interesseret i multilaterale løsninger for landene i regionen, fordi det kan danne model for, hvordan an- dre internationale problemer kan håndteres, fx eftersøgningen efter olie og råstoffer i det arktiske område. Det kan også spille ind, at militæret blander sig mere end hidtil i udenrigspolitikken, og at indenrigspolitiske spørgsmål i det hele taget vejer meget tungt.

\section{Indenrigspolitik i forgrund}

Den australske Kina-ekspert Linda Jakobson, Lowe Institute, mener, at den nye kinesiske ledelse er så optaget af indenrigsforhold, at landet i for høj grad kun vil reagere på udenrigspolitiske begivenheder i stedet for at lægge en meget aktiv linje, og at det kan føre til utilsigtede problemer.

Der er ingen tvivl om, at de interne udfordringer er store. Utilfredsheden med magtmisbrug og korruption er stor, og de høje boligpriser gør det vanskeligt for millioner af lønmodtagere at kunne købe deres egen bolig. De riges velstand skaber stigende utilfredshed, og latente oprør lurer rundt om i landet. Omvendt har ledelsen ofte været hurtig til at løse akutte problemer med $ø$ konomiske eller politiske midler. Ingen konflikt, fx blandt en gruppe bønder eller chauffører, har fået lov til at brede sig.

Omfattende reformer er sandsynlige i den kommende tid, fx på det finansielle område, herunder ved at markedet bestemmer renten til gavn for borgerne. Der er lagt op til be- 
skatning af velhaveres boliger, og på en række sociale områder er der bebudet reformer. Men det er også realistisk med politiske reformer, så befolkningen i højere grad inddrages i beslutningsprocessen, i første omgang formentlig på lokalt niveau.

Befolkningens utilfredshed med de eksisterende forhold har fået den nye ledelse til at give trouble-shooteren par excellence, Wang Qishan, jobbet som ansvarlig for bekæmpelsen af korruption. Man kan sige, at det er en degradering fra rollen som chef for erhvervs- og finanspolitikken og som den centrale partner over for USA i den strategiske dia$\log$.

Men at løse korruptions- og magtmisbrugsproblemet er utvivlsomt det største problem for partiet, fordi det griber ind i magtens cirkler, og derfor bliver Wangs bestræbelser en nøglefaktor i at skabe en effektiv ledelse, der kan få folkelig opbakning. Med den nye informationsalder er det formentlig uundgåeligt, at det også fører til en vis folkelig medindflydelse. Lykkes Wangs bestræbelser ikke, står Kina over for en særdeles urolig periode. Hans arbejde er den lim, der skal holde samfundet sammen, mens der gennemføres reformer.

Både Xi og den nye ministerpræsident Li Keqiang har direkte og indirekte udtrykt sympati for større folkelig medindflydelse. Xi har i flere år været leder af partiskolen i Beijing, og hér udvikles der ideer om, at partiets ledere skal udsættes for konkurrence, så de tvinges til at gøre et godt stykke arbejde, og partimedlemmerne skal have flere valgmulighederne ved valgene. Det interne demokrati blandt de godt 70 millioner partimedlemmer skal styrkes. Xi selv får en central opgave, fordi han leder det arbejde, der skal fastlægge rammerne for et Hongkong, der i hvert fald officielt skal have frie valg i 2017. Derfor bliver Hongkong en test på, hvordan Kina politisk vil udvikle sig i Xi's periode.

Det er samtidig værd at have i baghovedet, hvor systematisk den kinesiske ledelse $\mathrm{i}$ årevis har studeret gode og dårlige styreformer $i$ andre lande og situationer fra Singapore til Sovjetunionens sammenbrud. Der træffes ikke mange beslutninger, uden at de er gennemanalyseret.

Den nye politiske ledelse har en overvægt af ældre, moderate ledere, og det er blevet tolket som udtryk for, at der ikke kommer reformer. Men de fleste skiftes ud midtvejs i den nuværende ledelses ti års periode, og derfor kommer det store ryk med reformer måske først om fem år - og efter at Xi og Li har fået konsolideret sig, og når hele ledelsen har skabte mere solide rammer om den indenrigspolitiske udvikling, især om god regeringsledelse, en kinesisk version af corporate governance.

Men at den nye ledelse er meget optaget af de indre forhold er ikke ensbetydende med, at den vil optræ- 
de tilbageholdende i udenrigspolitikken, tværtimod. Med en årlig vækstrate på 7-10 pct. har Kina behov for åbne kanaler til omverdenen. Kina sluger halvdelen af verdens energi og halvdelen af mange råvarer, og den stærkt voksende middelklasse gør Kina til et så åbenlyst marked for virksomheder i industrilandene, at også Vesten er nødt til at have gode relationer til Kina trods nok så mange isolerede konflikter.

I dette spil bliver Kina den vigtigste aktør, også ved at forsvare sine interesser kontant, og det er værd at hæfte sig ved, at ledelsen i arbejdsrapporten fra sidste års partikongres skrev, at Kina "aldrig bøjer sig for udenlandsk pres.” Den slags ordvalg fandtes ikke i rapporten fire år tidligere.

I en tid, hvor Kina er blevet økonomisk bomstærk, og hvor der er betydelige sociale og politiske udfordringer på hjemmebanen, kan Xi ikke optræde svagt. Det nager stadig kineserne at se tilbage på ydmygelserne over for udenlandske magter, og derfor higer de efter en slags genrejsning. At blive verdens bedste i sport eller forretningslivet er en mægtig drivkraft for mange kinesere. Politisk vil de have respekt og anerkendelse.

\section{Senkaku/Diaoyu}

De første tegn på, hvordan et selvbevidst Kina vil optræde internationalt, kan blive i striden med Japan om Senkaku/Diaoyu-øerne i Det $\emptyset$ stkinesiske Hav. Indtil sidste år var øerne overhovedet ikke noget problem mellem de to lande. I 1978 gik Deng med til at lægge spørgsmålet om øerne 'til side,' og dermed skulle det være fremtidige generationer, som måtte finde en løsning. I sig selv har øerne ingen betydning for Kina. De ligger ca. $400 \mathrm{~km}$ fra det kinesiske hovedland og $400 \mathrm{~km}$ fra den japanske ø Okinawa, samt adskillige hundreder kilometer fra de japanske hovedøer.

Uanset om der kan fastlægges et historisk tilhørsforhold til øerne, så handler striden reelt om retten til undergrunden, nemlig om olie, gas og mineraler, og derfor er striden først blevet aktuel i nutiden med kinesernes hæsblæsende jagt på energi og råstoffer. Alene i Det Sydkinesiske Hav er der gas og olie, som vil fordoble Kinas nuværende reserver, skønner eksperter.

Den japanske regering forsøgte måske at forhindre en konflikt ved at købe øerne, der i mange år har været i privat eje, for at undgå, at bystyret i Tokyo ville købe øerne. Tokyo's nationalistiske borgmester, Shintaro Ishihara, har sagt, at japanernes massevoldtægt og massedrab på 200.000 civile i Nanjing i 1937-38 aldrig fandt sted. Han er fortaler for, at Japan får atomvåben.

Den japanske regering ville formentlig undgå at provokere Kina ved at købe øerne for næsen af Tokyo, men dér forregnede regerin- 
gen sig. Købet førte til en kinesisk kampagne for at få øerne tilbage. I september var der boykot af japanske biler, så salget faldt med 30-40 procent, og der har siden hen været skærmydsler i havet og luftrummet ved øerne, omfattende civile fartøjer og militære.

Med Shinzo Abe som ny japansk premierminister er der kommet en regeringschef, der lige som Xi slår de nationale toner an. Under valgkampen sidste år talte Abe om at ændre Japans pacifistiske forfatning. Det er ikke kun Kina, men hele Østasien, der frygter, at Japan vil ændre sin status og etablere et lidt mere 'normalt' forsvar, og Abe har også talt om at styrke den japansk-amerikanske alliance. Samtidig har Abe været på rundtur til flere lande $\mathrm{i}$ Sydøstasien for at skabe opbakning til dét, han kalder en asiatisk sikkerheds-diamant - et samarbejde, der tydeligt er vendt mod Kina. Diamanten skal efter hans opfattelse omfatte USA, Japan, Australien og Indien. Han har især udtrykt et ønske om at styrke et forsvarspolitisk og økonomisk samarbejde med Indien, ligesom han tilbyder betydelig økonomisk samarbejde med en række sydøstasiatiske lande, hvor Japan allerede er den største investor.

At styrke den japansk-amerikanske alliance vækker modstand i USA, som frygter, at en oprustning og en tættere alliance kan forværre konflikten med Kina. USA har sendt diplomater til begge lande for at finde en mindelig løsning. USA har påpeget, at skærmydslerne i havet ikke er i strid med international ret, og at en konflikt om øerne ikke er ensbetydende med, at USA skal komme sin allierede til undsætning. USA siger, at det ikke vil tage stilling til 'den ultimative suverænitet', og at øerne i dag er 'under japansk administration.' Dermed har USA tydeligt undladt at sige, hvem der i sidste ende har ejendomsretten til øerne.

Også Australien har meldt ud: Landet holder sit neutralt, selv om Australien politisk er knyttet langt tættere til Japan, for økonomisk er Kina en væsenlig større faktor for Australien. Det eneste land, der støtter en japansk genoprustning, frigjort fra sin pacifistiske forsvarspolitik, er Filippinerne, der ønsker Japan som en afbalancerende faktor over for Kina.

Trods barske udtalelser fra Kina og Japan, er kontakten mellem regeringerne opretholdt, bl.a. via sendebud fra Abe til Xi. Men skærpes konflikten kan det få alvorlige konsekvenser, i første omgang ved at bremse samhandelen mellem de to. De økonomiske konsekvenser er mest alvorlige for Japan, men selv Kina har en interesse i at opretholde forbindelserne, fordi de japanske investeringer giver flere millioner arbejdspladser og teknologioverførsler. Desuden vil en skærpet konflikt føre til en japansk oprustning, som ikke er i Kinas interesse. 


\section{Aftale, men ikke afklaring}

En sandsynlig udgang på konflikten er, at begge lande om nogle måneder eller år indgår en aftale om en fælles udnyttelse af fiskeressourcerne og af havbundens ressourcer uden at tage stilling til øernes endelige tilhørsforhold. Kina er vant til den form for uafklarethed, nemlig med Hongkong og Taiwan. Kina og Japan har allerede indgået en aftale om fælles udnyttelse af olieudvinding i et område i den nordlige del af Det Østkinesiske Hav, selv om aftalen ikke er blevet virkeliggjort endnu, formentlig på grund af modstand fra kinesiske energiselskaber.

Linda Jakobson har i en analyse peget på, at de to lande kunne enes om fælles overvågning af farvandet, så skibe fra de to lande på skift patruljerer. Det kunne begrundes i, at patruljeringerne skal hindre fiskere $i$ at tørne sammen. Men det ville også give Kina et alibi for at lade krisen ligge til en fremtidig afgørelse, for så står det stadig uafgjort, hvem øerne tilhører, nøjagtigt som på Dengs tid. Så er en af Kinas kerneinteresser forsvaret!

En sådan politik kan være afgørende for forholdet til Sydøstasien, ja til det globale samarbejde om bl.a. råstofudvinding. Kina var i mange år en meget aktiv partner for Sydøstasien, ikke mindst i ASEAN-samarbejdet, herunder ved at lave valutaaftaler, der stiller store beløb til rådighed, hvis nogle af landene havner i kriser som i 1997. Men siden 2010 er forholdet mellem Kina og naboerne kølnet, selv hos den nære partner Myanmar. Det er primært Kinas selvbevidste optræden, ikke mindst militært, samt kravene til territorier i Det Sydkinesiske Hav, som har skabt uro i Sydøastasien. Alle lande omkring havet stiller krav om ændrede grænser: Kina, Vietnam, Brunei, Malaysia (Borneo), Taiwan og Filippinerne. Selv Indien er aktiv med olieefterforskning.

Det har fået nogle lande til at dyrke forbindelsen til USA, men på den anden side er flere lande også imod at skulle vælge side. Hvis det endelig skulle komme dertil, har Singapore tydeligt gjort det klart, hvad præferencen er ved at sige, at Kina vil være en faktor de næste 1000 år, mens det er usikkert, hvor USA står om 100 år. Singapore har argumenteret for at lave aftaler for havterritoriet mellem de direkte involverede lande, altså regionale aftaler uden USA og Japan. Det går imod Kinas politik om at lave bilaterale aftaler, men det er dog mere spiseligt end multilaterale, globale aftaler.

Det kan selvfølgelig ikke udeukkes, at der kommer sammenstød mellem fartøjer fra Japan, Vietnam eller Filippinerne, men egentlige militære konflikter er næppe sandsynlige og skulle det ske, har Kina en interesse $i$ at begrænse dem mest muligt, for ellers skader det Kinas globale interesser.

Kina har behov for at udvinde rå- 


\section{BAGGRUND}

stoffer og energi i hele verden. Derfor er det mest sandsynlige, at Kina lægger op til forhandlingsmønstre, som kan bruges i en international sammenhæng. Kina udnytter råstoffer i Afrika både til lands og til vands. Kina ventes i fremtiden at hente råstoffer overalt i Stillehavsområdet. Kina har brug for havnerettigheder i Asien, og Kina har brug for at hente olie, gas og mineraler på Grønland og i Nordpolsområdet.

\section{Arktis}

Med udvindingen i det arktiske område kommer Danmark i diplomatisk nærkontakt med Kina, der har arbejdet intenst i flere år på at komme ind i varmen og blive permanent observatør i Det Arktiske Råd, som består af de lande, der støder op til det arktiske område. Kina betragter sig som en arktisk stakeholder eller en næsten-arktisk stat. Det er ikke kun råstofudvinding, herunder af vigtige mineraler på Grønland til industriproduktionen, som har Kinas interesse, men også at kunne sejle nord om Rusland. Den globale opvarmning får isen til at smelte, så det er muligt at sejle i farvandet nogle måneder hvert år. En skibstransport kan reduceres fra seks til to uger ved at sejle nord om Rusland til Vesteuropa.

Kina forsøger at knytte sig tæt til Nordpolens randstater via bidrag til fx forskningen, og det er tydeligt, at Kina holder en lav profil, når det drejer sig om rettigheder. I dette område gælder diplomatiet i allerhøjeste grad, og derfor har Kina intet problem med at have gode forbindelse til Norge, der er hjemsted for Det Arktiske Råds sekretariat, trods Kinas utilfredshed med, at Nobels fredpris i 2010 gik til systemkritikeren Liu Xiaobo.

Det er langsigtede og globale interesse, der er på spil for Kina, som mener, at det arktiske område vedrører alle lande på kloden, og at alle skal kunne have adgang til råstofferne. Ledelsen i Beijing begrunder bl.a. sin holdning med klima-problemet. Det er en interessant begrundelse, for dermed anvender Kina multilaterale eller globale argumenter.

Dermed er stridighederne om havterritorierne i nærområdet kædet sammen med det arktiske område samt med globale udvindingsrettigheder, sejlads og klima-problemer. Det vil være svært for Kina at bruge militære midler eller bulldozer-agtige bilaterale aftaler i én region og et renlivet diplomati i andre områder. Hvordan kineserne vil lægge snitfladen i sin fremgangsmåde i udenrigspolitikken bliver uhyre interessant. Er kerneinteresser på spil, er der ingen tvivl om, at Kina vil vise sin styrke uden at sætte de voksende globale, multilaterale og diplomatiske interesser over styr. Kina har over for Vietnam og Indien ført grænsekrige, men i begrænset omfang, så det ikke har skadet landets 
langsigtede relationer. Det er en politik, der minder forbavsende meget om kansler Bismarcks samling af Tyskland i 1800-tallet. Han indlod sig på begrænsede grænsekrige, men undlod at ekspandere ud over det, han kaldte Tysklands naturlige grænser.

\section{Nordkorea}

Kinas holdning til Nordkoreas atomvåbenpolitik vil give en vis afklaring på udformningen af udenrigspolitikken. Kina har kritiseret de atomare prøvesprængninger, men i mildere toner end USA, Sydkorea og Japan. Kina har været med til at vedtage FN-sanktioner, men har hele tiden forsøgt at gøre dem så milde som muligt, så Kina kunne været med i de énstemmige resolutioner i FN's sikkerhedsråd, der kræver afvikling af atomvåbenprogrammet og stop for udviklingen af ballistiske missiler.

Kina er nødt til at skræve vidt for at håndtere atomvåbensagen over for Nordkorea, som Kina forsvarede under Koreakrigen. Kina er Nordkoreas vigtigste partner, og Nordkorea kan blive en vigtig 'leverandør' af arbejdskraft til en sulten kinesisk industri, evt. i industrizoner, som Kina forsøger at få Nordkorea til at etablere efter kinesisk model. Men det afgørende mål for Kina er at sikre fred og stabilitet på den koreanske halvø og i forholdet til Japan. Atomvåben i Nordkorea kommer længere nede på prioriteringslisten.

Dér, hvor atomvåben får en første prioritet er, hvis Nordkorea udvikler et så stærkt atomvåbensystem, at det tvinger Sydkorea og Japan til at udvikle egne atomvåben, og USA så involverer sig meget stærkere i regionen. Hér kommer testen på Kinas udenrigspolitiske formåen. Nordkorea har ikke økonomisk kapacitet til at udvikle et fuldt udviklet atomvåben- og missilsystem, så de nuværende initiativer er snarere en politisk demonstration. Kina kan som den altafgørende partner være bestemmende for Nordkoreas økonomiske og militære formåen.

Da der er klare indikationer af, at den unge leder, Kim Jong Un, ønsker mere åbne forhold til omverdenen, men at han også må vise sig stærk indadtil, er det sandsynligt, at de nordkoreanske atomvåben kan holdes på et så begrænset niveau, så det ikke vil føre til et regionalt atomvåbenkapløb. Er den udvikling mulig, vil Kina også vise omverdenen, at det kan flytte grænsepæle for at klargøre sine kerneinteresser.

Hvis Nordkorea virkelig vil åbne op for $\varnothing$ konomisk samkvem, fx ved at etablere flere industrizoner á la Kaesong Zonen på grænsen mellem Nord- og Sydkorea for udenlandske virksomheder, kan det måske føre til en international accept af et stærkt begrænset og kontrolleret atomprogram. Men en sådan udvikling har storpolitiske perspektiver, for det kan åbne døren for atomvåben i an- 
dre lande, primært Iran, så derfor bliver også en sådan situation vanskelig at håndtere.

Nærområderne vest for Kina, dvs. Centralasien og Sydasien med fx Pakistan og Iran, har lige så stor strategisk betydning for Kina som Koreahalvøen. Det er fx terrorbekæmpelse, olie og samhandel, der er på spil. Med den økonomiske krise i Vesten får den arabiske verden med ca. 400 millioner forbrugere voksende betydning for Kina, der samtidig bliver det vigtigste oliemarked for SaudiArabien og landene ved Golfen. Beijing har traditionelt været meget tilbageholdende i Mellemøsten, men har dog i de seneste måneder gjort forsøg på at spille en vis rolle i Syrien og i konflikten om Palæstina. Regionen bliver nok ikke en 'kerneinteresse' for Kina, men den får stærkt voksende betydning økonomisk og strategisk.

Det sker, mens USA trækker sig tilbage og reducerer sin olieimport dramatisk. Kina er dermed langsomt ved at træde i USA's sted, økonomisk, og ikke militært. Da Kinas interesser ikke bare ligger i olien, men også i Mellemøsten som marked og som produktionsbase for eksport til Europa, har Kina også en vital interesse i stabilitet og vækst i regionen. Det er vidtrækkende perspektiver, der tegner sig.

At Kina fokuserer på økonomien, ses i særdeleshed over for Europa. Selv om EU forsøger at optræde stærkere udadtil, så er det Tyskland, som kineserne primært dyrker. Det udtrykkes bl.a. i de fælles regeringsmøder mellem Kina og Tyskland à la den strategiske dialog med USA. Berlin er vigtigere end Bruxelles, dels fordi Tyskland er den helt afgørende aktør i EU, dels fordi de tyske investeringer i Kina er med til at skabe kernen i den kinesiske industri.

Konsekvensen af kinesernes økonomiske styrke ignoreres generelt i Europa og USA. Det er slående, at den amerikanske efterretningsrapport fra sidste år, Global Trends 2030 fra National Intelligence Council, NIC, ikke fik nogen særligt omfattende dækning i medierne. Dens konklusioner er ellers barske. Den forudser afslutningen på USA's eneherredømme inden 2030. Den forudser, at Kina og Indien vil blive mere magtfulde end USA og Europa i 2030 - og med magt menes både økonomisk, militært, teknologisk og forbrugermæssigt. USA og Europa vil være på en konstant nedtur.

Ifølge rapporten, som også CIA har bidraget til, vil Kina dog ikke overtage USA's strategiske og globale rolle, fordi USA har langt større indflydelse verden over. Men rollen som en unipolær magt i Pax Americana reduceres hurtigt, og Asien vil overgå resten af verden i økonomisk og militær magt. Rapporten fastslår, at alle tidligere fire-årige rapporter fra NIC har undervurderet tempoet i de seneste års forandringer. Det er ikke just den slags vurderinger, der 
lyder fra de vestlige politiske ledere. (Se anmeldelse af Global Trends 2030 side 114 i dette nr. af Udenrigs).

Ved en traditionel sammenligning kan Kina ikke hamle op med USA rent militært, men med teknologiens voksende betydning er den traditionelle militærbalance blevet mindre vigtig. Kina har lært af den første Irakkrig, hvor Vestens luftherredømme viste sig at være afgørende, og kineserne har siden hen satset massivt på teknologi for at kunne sikre sig herredømmet i luften og rummet. Derfor bygges der fx ikke krigsskibe i stort omfang, men Kina vil med satellitter og missiler sikre sig, at det under en konflikt kan hindre amerikanske skibe $i$ at trænge ind i de vitale kinesiske farvande ved at ramme amerikanske skibe og styrker langt ude i Stillehavet (anti-access/anti-denial). Kina satser massivt på cyberwar. Forsøgene på at lamme de iranske atomanlæg med computervirus viser, at en fremtidig konflikt også vil blive udkæmpet med cyberangreb, og det er slående, at USA's tidligere forsvarsminister, Leon Panetta, har advaret om risikoen for et cyber-Pearl Harbor, ikke bare i krigstid.

\section{Udgør Kina en trussel?}

Det afgørende i en højteknologisk oprustning er kapital. I de kommende år og årtier kan Kina investere langt mere end USA i højteknologisk forsvar. Kina overrasker kon- stant på det teknologiske område - i forskningen, erhvervslivet og i forsvaret, fx med en kraftig udvikling af droner og stealth-fly.

Udgør det så en risiko? Den vestlige diplomat, der har haft mest kontakt med Kina i længst tid, er Henry Kissinger, og han hæfter sig ved, at Kina slet ikke har nogen tradition for magtpolitisk eller militær ekspansion, men derimod har Kina altid forsøgt at gøre sig usårlig over for omverdenen.

Det er denne specielle kinesiske filosofi og styrke, der så at sige blev manifesteret sidste år. Det virker som en fredelig udvikling, men kan USA leve med at blive overhalet på $\mathrm{i}$ hvert fald en række områder? Brzezinski har stillet spørgsmålet, om de to supermagter kan anerkende hinanden som ligestillede, så ingen søger overherredømme.

Hvis USA mener, at Kina først skal indordne sig under de vestlige spilleregler, eller hvis Kina vil udvikle sig på grundlag af egne principper, så er der selvklart risiko for fremtidige konfrontatiner, og historien har altid vist, at nye stormagters opdukken altid fører til konflikter. Det paradoksale er, at situationen ligner tiden op til Første Verdenskrig, hvor England og Tyskland med vidt forskellige verdensbilleder så hinanden som en trussel og ikke som medspiller.

Det er slående, at en række amerikanske eksperter og tidligere embedsmænd som Joseph Nye fra Har- 


\section{BAGGRUND}

vard for nylig var i Kina og Japan med det formål at drøfte, hvordan en gentagelse af 1914 kan undgås. Vi får næppe en verden med ét sæt spilleregler, og der kan blive stor uenighed om vægtningen af $\mathrm{fx}$ bilaterale og multilaterale konstruktioner. USA har ikke hidtil haft besvær med at leve med Kina - så længe Kina var den lille part. Hvordan bliver det, når Kina bliver den toneangivende på væsentlige områder? Derfor bliver spørgsmålet, i hvor høj grad de forskellige systemer og interesser kan fungere sammen, ja, endog udvikle sig sammen, når Kina bygger på sit eget verdensbillede og - ifølge Kissinger - lader klassiske lærdomme, fx om human autoritet, veje tungere end udenlandske ideologier i udformningen af indenrigs- og udenrigspolitikken.

Kissinger bruger i sin bog udtrykket co-evolution om den strategi, som han mener, Kina og USA er nødt til at etablere for at undgå en klassisk konflikt mellem en opstigende og en faldende stormagt. Allerede nu ser vi, at han har været forud for sin tid, for det er tydeligt, at Kina i stigende grad sætter sin egen dagsorden og maler sit eget verdensbillede.

Hugo Gården er freelance-journalist, bosiddende i det kinesiske økonomiske vekstcentrum Shanghai. 